\begin{tabular}{|c|c|c|c|}
\hline \multirow{2}{*}{$\begin{array}{r}\text { Case Reports in } \\
\text { Gastroenterology }\end{array}$} & \multicolumn{2}{|c|}{ Case Rep Gastroenterol 2017;11:359-363 } & \multirow[b]{2}{*}{$\begin{array}{l}\text { Karger } \\
\text { Open access }\end{array}$} \\
\hline & $\begin{array}{l}\text { DOI: 10.1159/000475920 } \\
\text { Published online: IVay 30, } 2017\end{array}$ & $\begin{array}{l}\text { (c) } 2017 \text { The Author(s) } \\
\text { Published by S. Karger AG, Basel } \\
\text { www.karger.com/crg }\end{array}$ & \\
\hline & $\begin{array}{l}\text { This article is licensed under } \\
\text { International License (CC BY- } \\
\text { Usage and distribution for comn }\end{array}$ & $\begin{array}{l}\text { nons Attribution-NonCommercial } \\
\text { ger.com/Services/OpenAccessLice } \\
\text { uires written permission. }\end{array}$ & \\
\hline
\end{tabular}

\title{
Acute Pancreatitis: An Atypical Presentation
}

\author{
Omar Nadhem Omar Salh \\ Internal Medicine Department, Texas Tech University Health Sciences Center, \\ Amarillo, TX, USA
}

\section{Keywords}

Acute pancreatitis $\cdot$ Lipase $\cdot$ Amylase $\cdot$ Abdominal pain

\begin{abstract}
Acute pancreatitis is an important cause of acute upper abdominal pain. Because its clinical features are similar to a number of other acute illnesses, it is difficult to make a diagnosis only on the basis of symptoms and signs. The diagnosis of acute pancreatitis is based on 2 of the following 3 criteria: (1) abdominal pain consistent with pancreatitis, (2) serum lipase and/or amylase $\geq 3$ times the upper limit of normal, and (3) characteristic findings from abdominal imaging. The sensitivity and specificity of lipase in diagnosing acute pancreatitis are undisputed. However, normal lipase level should not exclude a pancreatitis diagnosis. In patients with atypical pancreatitis presentation, imaging is needed. We experienced two cases of acute pancreatitis associated with normal serum enzyme levels. Both patients were diagnosed based on clinical and radiological evidence. They were successfully treated with intravenous fluids and analgesics with clinical and laboratory improvement. The importance of this case series is the unlikely presentation of acute pancreatitis. We believe that more research is needed to determine the exact proportion of acute pancreatitis patients who first present with normal serum lipase, since similar cases have been seen in case reports.
\end{abstract}

(C) 2017 The Author(s)

Published by S. Karger AG, Basel

KARGER
Omar Nadhem, MD

Internal Medicine Department, Texas Tech University Health Sciences Center

1400 S Coulter

Amarillo, TX 79106 (USA)

E-Mail omarnadhem82@gmail.com 


\section{Introduction}

Acute pancreatitis (AP), an inflammatory disorder of the pancreas, is the leading cause of admission to hospital for gastrointestinal disorders in the USA and many other countries [1]. The diagnosis of AP requires 2 of the following 3 features: (1) abdominal pain characteristic of AP, (2) serum amylase and/or lipase $\geq 3$ times the upper limit of normal, and (3) characteristic findings of AP on CT scan [2]. During AP, serum lipase increases within 4-8 h, peaks at $24 \mathrm{~h}$, and remains elevated for 1-2 weeks, with a half-life between 7 and $14 \mathrm{~h}$ [3]. Lipase is more sensitive and specific than amylase in diagnosing AP, with a negative predictive value of $94-100 \%$ [4]. AP in the setting of normal amylase and lipase has been rarely described in the literature. However, the absence of elevated lipase should not exclude its diagnosis [5]. In patients with abdominal pain characteristic of AP and serum enzyme levels that are normal or $<3$ times the upper limit of normal, CT scanning provides an accurate confirmation of the diagnosis and offers an excellent anatomic and morphologic representation of the pancreas and peripancreatic tissue $[2,6]$. We report a case series of two patients who presented with epigastric abdominal pain and were found to have AP by abdominal CT scan despite having normal serum amylase and lipase levels.

\section{Case Reports}

\section{Case 1}

A 40-year-old white female with a past medical history of hypertension and bipolar disorder presented with a few hours of severe sharp epigastric abdominal pain radiating to the back associated with nausea and vomiting. The patient denied any history of pancreatitis, consuming alcohol, or illegal drug abuse. No new medication had recently been started, and there was no history of abdominal trauma. She had had a cholecystectomy in 2004. On physical examination, she was afebrile, had a heart rate of 105 beats $/ \mathrm{min}$, and a blood pressure of $132 / 84 \mathrm{~mm} \mathrm{Hg}$. She was in severe distress due to pain with severe epigastric tenderness. The remainder of her physical exam was normal.

Her laboratory tests on admission revealed a WBC of $22.1 \times 10^{3} / \mu \mathrm{L}$ with neutrophils $87 \%$, a hemoglobin level of $14.0 \mathrm{~g} / \mathrm{dL}$, and platelets $380 \times 10^{3} / \mu \mathrm{L}$. Her comprehensive metabolic panel was unremarkable except for a potassium level of $2.7 \mathrm{mEq} / \mathrm{L}$. She had a negative pregnancy test and a normal urine drug screen. Her serum amylase was $31 \mathrm{IU} / \mathrm{L}$ (normal ref: 20-160) and lipase was 14 IU/L (normal ref: 8-78).

Since the patient was in severe pain with no clear diagnosis, a CT scan of her abdomen with intravenous contrast was done in the emergency room. The CT scan showed fat stranding in the pancreatic head consistent with pancreatitis and reactive thickening in the duodenum (Fig. 1). The patient was admitted to the floor and kept nothing by mouth. She was treated with intravenous fluids, analgesics, potassium supplement, and antiemetics. On the next morning, repeated measurements of her amylase and lipase were still within normal limits. We checked her triglyceride level and it was $53 \mathrm{mg} / \mathrm{dL}$. Her symptoms continued to improve during her course of hospitalization, and her leukocytosis was resolved without the use of antibiotics. She was discharged home on day 3.

Case 2

A 45-year-old white male with a history of alcohol abuse presented with severe epigastric abdominal pain that lasted for approximately $12 \mathrm{~h}$. The pain was sudden in onset, radiat- 
ing to the back, and associated with nausea and vomiting. His last alcoholic drink was 1 day prior to presentation. He had had a cholecystectomy 4 years ago. On physical examination, his vital signs were within normal limits with epigastric tenderness.

His laboratory tests on admission revealed a WBC of $12.6 \times 10^{3} / \mu \mathrm{L}$, a hemoglobin level of $13.6 \mathrm{~g} / \mathrm{dL}$, and platelets $172 \times 10^{3} / \mu \mathrm{L}$. His comprehensive metabolic panel was remarkable for AST 98 IU/L (normal ref: 8-42) and ALT 43 IU/L (normal ref: 7-40). He had a negative viral hepatitis panel and a normal urine drug screen. His serum amylase and lipase levels were $55 \mathrm{IU} / \mathrm{L}$ and $28 \mathrm{IU} / \mathrm{L}$, respectively. A CT scan of the abdomen with intravenous contrast showed a stranding edema within the peripancreatic fat suggestive of AP (Fig. 2). The patient was treated with intravenous fluid, analgesics, and antiemetics. His serum amylase and lipase levels were normal throughout the admission. Two days later, he was discharged home with complete resolution of his symptoms.

\section{Discussion}

$\mathrm{AP}$, an inflammatory disorder of the pancreas, is the leading cause of admission to hospital for gastrointestinal disorders in the USA and many other countries [1]. It has been estimated that in the United States there are 210,000 admissions for AP each year [2]. AP is a potentially fatal disease with a mortality rate of $5 \%$ in the United States. Given the dangers of misdiagnosing pancreatitis, awareness of unusual presentations is paramount [2, 5]. Alcohol use, gallstones, hypertriglyceridemia, hypercalcemia, medications, endoscopic retrograde cholangiopancreatography, and trauma account for most cases of AP; however, approximately 20\% remain idiopathic [7]. Most patients with AP experience abdominal pain that is located generally in the epigastrium, and radiates to the back in approximately half of the cases. The onset may be swift with pain reaching maximum intensity within $30 \mathrm{~min}$, frequently unbearable, and characteristically persisting for more than $24 \mathrm{~h}$ without relief. The pain is often associated with nausea and/or vomiting [2].

The diagnosis of AP requires the presence of 2 of the following 3 criteria: (1) characteristic abdominal pain, (2) serum amylase and/or lipase $\geq 3$ times the upper limit of normal, and (3) CT scan findings compatible with AP $[2,7]$. In AP, usually, serum lipase increases within 4-8 h after onset of symptoms, peaks at $24 \mathrm{~h}$, and returns to normal after 8-14 days $[3,7]$. The sensitivity and specificity of amylase and lipase are reported to be considerably dependent on the detection method used, ranging from 70 to $100 \%$ and from 33 to $89 \%$ for serum amylase, and from 74 to $100 \%$ and from 34 to $100 \%$ for serum lipase, respectively [6]. Several studies have reported the negative predictive value of serum lipase in diagnosing AP to be $94-100 \%[4,7]$. Factors that can lead to normal amylase and lipase values are hypertriglyceridemia, extensive pancreatic necrosis (acute fulminant or acute-on-chronic pancreatitis) [6], or very early pancreatitis when inflammation has not led to a lot of pancreatic acinar cell destruction yet (which was not the case in our patients as repeated measurements of the enzyme levels were still normal) [8]. Serum trypsinogen activation peptide and trypsinogen-2 are more specific early markers for pancreatitis but are expensive and not readily available $[7,8]$.

A contrast-enhanced CT scan is the best imaging technique to diagnose pancreatitis in patients with atypical presentations, exclude other etiologies of acute abdominal pain, evaluate the severity, and identify complications of AP $[2,6,8]$. The clinical severity of AP is stratified into 3 categories according to the revised Atlanta classification: mild (no organ failure), moderately severe (transient organ failure $<48 \mathrm{~h}$ ), and severe (persistent organ 
Nadhem and Salh: Acute Pancreatitis: An Atypical Presentation

failure $>48 \mathrm{~h}$ ). The treatment of AP consists of fluid resuscitation, pain management, and nutritional support $[1,2,7]$.

\section{Conclusion}

Relying solely on high serum lipase and/or amylase levels to establish the diagnosis of $\mathrm{AP}$ is reasonable, but increased awareness is needed in the setting of AP with normal enzyme levels. An abdominal CT scan is essential in establishing the diagnosis of AP in patients with atypical presentations.

\section{Statement of Ethics}

The authors wish to thank the patients who kindly gave consent for their cases to be presented in this report.

\section{Disclosure Statement}

The authors declare that none of them has a conflict of interest regarding the publication of this paper. There were no funding sources.

\section{References}

1 Lankisch PG, Apte M, Banks PA: Acute pancreatitis. Lancet 2015;386:85-96.

-2 Banks PA, Freeman ML: Practice guidelines in acute pancreatitis. Am J Gastroenterol 2006;101:2379400.

-3 Cartier T, Songi P, Perruche F, Meyniard O, Claessens Y-E, Dhainaut J-F, Sahakian GD: Normal lipase serum level in acute pancreatitis: a case report. Emerg Med J 2006;23:701-702.

4 Ko K, Tello LC, Salt J: Acute Pancreatitis with normal amylase and lipase. The Medicine Forum 2011;11:Article 4.

5 Zafar W, Chaucer B, Davalos F, Nfonoyim J: Scrotal swelling and normal lipase, a rare presentation of acute pancreatitis. Am J Emerg Med 2016;34:763.e5-763.e6.

-6 Khan FY, Matar I: Chylous ascites secondary to hyperlipidemic pancreatitis with normal serum amylase and lipase. World J Gastroenterol 2007;13:840-842.

7 Shah AM, Eddi R, Kothari ST, Maksoud C, DiGiacomo WS, Baddour W: Acute pancreatitis with normal serum lipase: a case series. JOP 2010;11:369-372.

-8 Singh A, Shrestha M, Anand C: Acute pancreatitis with normal amylase and lipase - an ED dilemma. Am J Emerg Med 2016;34:940.5e-940.7e. 


\section{Case Reports in Gastroenterology

\begin{tabular}{l|l}
\hline Case Rep Gastroenterol 2017;11:359-363 \\
\hline DOI: 10.1159/000475920 & $\begin{array}{l}\text { ○ 2017 The Author(s). Published by S. Karger AG, Basel } \\
\text { www.karger.com/crg }\end{array}$ \\
\hline
\end{tabular}

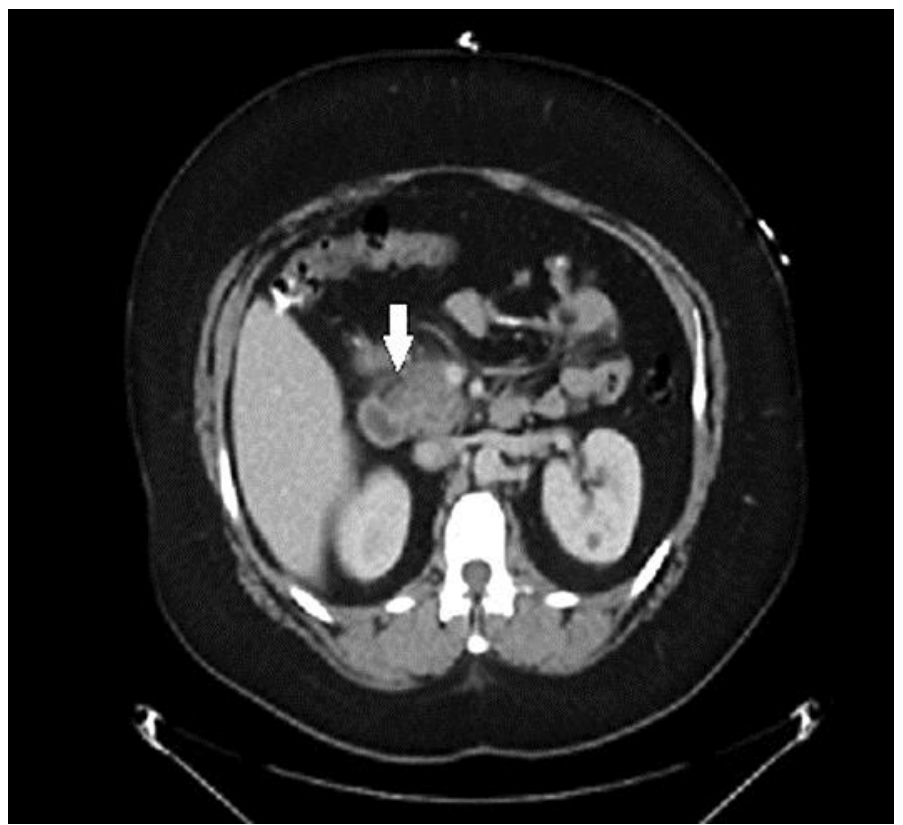

Fig. 1. An abdominal CT scan of case 1 showed fat stranding in the pancreatic head consistent with pancreatitis and reactive thickening in the duodenum (white arrow).

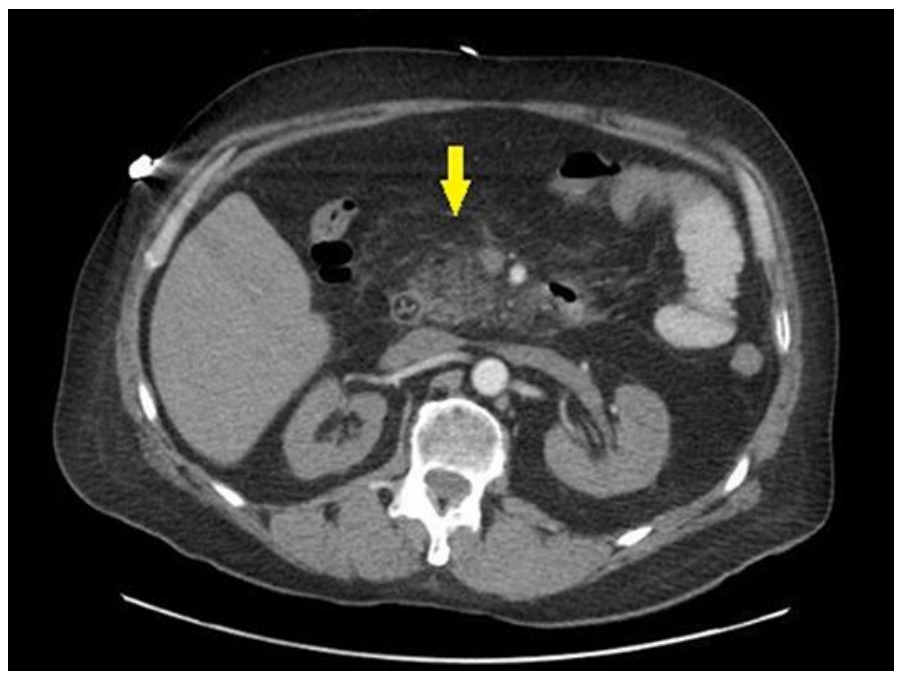

Fig. 2. An abdominal CT scan of case 2 showed a stranding edema within the peripancreatic fat suggestive of acute pancreatitis (yellow arrow). 